\title{
Employing Empathy to Teach and Assess the Learning Process in Controversial Historical Issues
}

\author{
Thomas K. Babalis, Elisabeth D. Lazarakou \\ Department of Pedagogy and Primary Education, National and Kapodistrian University of Athens, Athens, Greece \\ Email: tbabalis@primedu.uoa.gr
}

How to cite this paper: Babalis, T. K., \& Lazarakou, E. D. (2021). Employing Empathy to Teach and Assess the Learning Process in Controversial Historical Issues. Creative Education, 12, 1615-1628. https://doi.org/10.4236/ce.2021.127123

Received: June 7, 2021

Accepted: July 20, 2021

Published: July 23, 2021

Copyright $\odot 2021$ by author(s) and Scientific Research Publishing Inc. This work is licensed under the Creative Commons Attribution International License (CC BY 4.0).

http://creativecommons.org/licenses/by/4.0/

\begin{abstract}
In this paper, a proposal is presented concerning the teaching of a historical event through an emotional-experiential approach. The teaching approach refers to the historical event of the trial of the Athenian generals who were sentenced to death and executed immediately after their victory over the Spartan fleet in the Arginusae islands in 406 BC. We make use of the paradoxical decision of the Athenian citizens to execute their victorious generals in order to ask students a series of critical questions in the form of problems or dilemmas, in an aim to invigorate their reflection, nurture their thinking and to spark dialogue concerning issues of the past and the present. Along with understanding the action of historical persons, students are invited to evaluate their own beliefs and attitudes which are often biased and emotionally charged. The proposed teaching approach includes a series of empathic tasks which are in essence both teaching and assessment activities of student attitudes and beliefs as well as activities assessing the learning process. Conducting these activities ensures a continuous flow of information which can immediately be put to use in order to improve students' cognitive, social and emotional performance as well as to enhance the learning process itself. Assessment of the learning process constitutes an integral part of teaching and takes place during every moment of classroom instruction while at the same time serving formative and feedback functions.
\end{abstract}

\section{Keywords}

Historical Empathy, Critical Thinking, Perspective Taking, Assessment of the Learning Process

\section{Introduction}

It is widely accepted that the historical narrative does not constitute informative 
material to be memorized, but rather an open invitation to the reader, to the teacher and especially to the student for a personal meeting. A personal meeting of historical context means to be in a position to listen to the text and to develop a dialogue with it. In order to accomplish this, teachers need to disengage from the way they see things, from their own personal perspective as much as possible, avoiding in this way, a superficial and distortive approach. In order for teachers to heed the historical event, they must have smoothed out their own beliefs, their stereotypical perceptions and their own feelings beforehand. On the other hand, the experiences students have undergone also put up a strong resistance although they do not yet constitute crystallized beliefs. False and imaginary representations of the past, effectively transferred through popular culture, play an important role in shaping the historical consciousness of both teachers and students (Shemilt, 2011: p. 73). It is therefore important to train teachers and students in critical thinking, to develop the readiness to revise opinions, attitudes and behaviors.

\section{Empathy as a Tool for Understanding History}

For the history lesson it is necessary to penetrate the socio-political context of the historical period and to approach the ideas, beliefs and ways of action of historical individuals. The development of such a relationship with the past has been defined as historical empathy. Both the definition of the term and its implementation in the educational setting have provoked various contradictory positions and proposals (Jenkins, 1991; Foster, 2001; Lee \& Ashby, 2001). In an attempt to create a theoretical bridging of the existing definitions, we could say that historical empathy is the point at which we arrive when, after effort, vigilance and reflection, with the help of our intellect, imagination and sentiment, we manage to reconstruct a historical incident and create an imaginative representation of it. In this manner, we are able to capture and understand as far as possible the mental state, behavior and emotion of its historical protagonists within their own frame of reference (Lee \& Shemilt, 2011).

Historical empathy is an important tool for teaching controversial historical issues. These are referred to as historical dilemmas and controversial situations, which have provoked conflicting positions, strong emotions and intense controversy. Examined today in their historical context, these controversial historical issues often seem excessive, incomprehensible and open to different interpretations and for this reason their handling by both teachers and students should be done with critical thought, care and sensitivity (Goldberg \& Savenije, 2018; Phillips, 2009). It is exactly these controversial historical issues which are the most advantageous for comprehending history as a lesson that is significant for one's life. Aiding in this effort is the teachers' readiness to place themselves within the historical situation and to succeed in re-enacting the events. In the school context, students also have to delve into the historical evidence in order to speculate that which is not explicitly mentioned in it, but which is perhaps implied 
(Lazarakou, 2008; Lemisko, 2004).

\section{An Empirical Approach of a Historical Event: A Paradigm from the History of Ancient Greece}

A teaching methodology based on the empathic and experiential approach is subsequently developed (Tsoli, 2019). The purpose of the proposed teaching approach is to enable educators and students to engage in empathic activities in order to process views and attitudes, which are often invested with resistance and emotional load (Lazarakou, 2009). The paradigm is designed and based on a series of critical issues and critical questions. We characterize a critical question as one which is conciliated with an answer that surely requires critical thinking by the use of a logical process to come up with a result that has already been adopted by the corresponding science involved, in this case History. The critical issue, on the other hand, is generally not answered with an argument and is not satisfied with a response. In most cases, it is left unanswered in the end since the corresponding science, in this case History, has not come up with a clear-cut answer. This does not mean, of course, that the critical issue under discussion merely serves to put forward arguments which do not lead anywhere. Instead, it serves to activate critical thinking, to evaluate and possibly revise stereotypical assumptions. As a rule, the critical issue is that which is emotionally charged.

\subsection{The Denunciation of the Generals, Conquerors of the Naval Battle at Arginusae}

The proposed teaching approach exploits the historical event of the trial of the eight Athenian generals, who immediately after their glorious victory against the Spartan fleet just outside the Arginusae islands in 406 BC, were sentenced to death by the Athenian Assembly and were executed. The historical event constitutes one of the most excruciating moments of the Peloponnesian War, which ended up as a political and moral conflict of traumatic dimensions, one which had a dramatic conclusion. Surpassing the time period in history, it is proposed in this study that the specific historical event could offer even today valuable stimuli for reflection and dialogue as a teaching paradigm in the history lesson. The purpose of the teaching approach demonstrated in this study is to investigate both the explicit and obscure features of the reaction of the citizens of a democratic society when they are called upon to make critical decisions concerning their present and their future while in the vortex of precarious socio-political circumstances or while in the whirlwind of painful personal situations with the conviction or illusion that they serve justice or that they adhere to the city's moral beliefs.

\subsection{The Victorious Naval Battle}

The historical event evolves in two phases, the first one has to do with the victorious naval battle for the Athenians at Arginusae islands and the second 
concerns the generals' trial in the Athenian Assembly (Ecclesia). The Athenians who were weakened by many years of involvement in a devastating war and shortly after the tragic failure of the Sicilian campaign, having exhausted the last reserves of the Treasury, build ships by melting the golden statues of the Temple of Athena Nike on the Acropolis and man them with substandard crews which in this case were slaves and metics, the only available in the city (Xenophon, 1, 6, 24). The leadership of the mission was appointed to eight of the city's most capable generals (strategoi). Thanks to the application of innovative tactics, the Athenian fleet defeated the Spartan fleet under the command of the young Callicratidas, while only a small number of Spartan ships managed to escape.

The victory at the Arginusae islands was of great importance for Athens, as it brought enormous losses to the Spartan naval force, placing Athens at the forefront as a naval force once again and renewing hope for an ultimate victory in the war. It was marred, however, by the failure or inability of generals in charge to perform the task of rescuing the survivors of the shipwreck and who were responsible for the recovery of the dead and the wreck. The reason for not fulfilling this obligation was the severe storm at sea which prevented the men of Theramenes and Thrasybulus from carrying out the rescue mission assigned to them by the chief generals (Xenophon, 1, 6, 35, Diodorus Siculus, 13, 100, 2). According to the defense argument, the shipwrecks were scattered over a large extended area and men were reluctant to risk their lives to complete the rescue while the Spartans were imminent to return (Kagan, 2004: p. 644). The negligence or the inability of the generals to carry out their duty as they should have, resulted in the abandonment of those on the shipwrecks to their fate, to a certain death due to the storm. Moreover, those who died for their city were not buried and ships which had not been completely destroyed were lost.

\subsection{The Trial of the Generals}

For the ancient Greeks, securing a ritual burial for the dead comprised the same or even more important moral concern as rescuing the living. Failure to observe this obligation was rejected by common sense as it meant breaching the unwritten law. According to conventions, it was considered to be a very serious offense. Charged with violating their sacred duty, the eight generals were brought to trial before the Assembly, which, due to the gravity of the offense, operated as a court. In deep mourning and targeted deception, a daunting number of citizens/judges, overwhelmed by rage and indignation, lost all sense of justice, defrauded the laws of the Athenian state, impeded the rights of the accused and abused the powers of the democratic institutions. The efforts of Euryptolemus, the counselor of the defendants, to contravene the illegal procedure by opposing the motion on the grounds that it was unconstitutional, were unsuccessful (Xenophon, $1,7,34)$. The accused, being sentenced to the severest punishment, were led to execution. 


\section{Issues for Investigation}

Although the generals' obligation to collect the dead was irreversible, the brutal reaction of the Athenian Assembly obviously constitutes an extreme deviation which is difficult to comprehend. We exploit the element of incongruity and arbitrariness that characterizes the court ruling to ask our students a series of critical issues and critical questions which not only aim at a deeper understanding of the historical event but which also trigger reflection, fuel thought and generate dialogue about issues concerning the past and the present time.

Critical issues:

Feelings are capable of leading us to experience virtues but also appalling evil. Under the influence of negative emotions, we operate almost always spontaneously and behave irrationally breaking rules and laws. But when thinking reasonably, emotions are controlled, leading us to reach clear-headed decisions. Do you agree?

With a report to the Athenians documenting the fact that the dead and the wrecks had not been retrieved, the generals initially intended to describe the events in detail and to expose the trierarchs (the trireme's commanding officers), Theramenes and Thrasybulus, who failed to carry out their mission which was to rescue the wrecks and to collect the dead. Their first emotional reaction was to renounce any responsibility and to blame the two trierarchs. However, they thought things out logically, with composure. They felt that it would not be in their best interest to blame the trierarchs since that would bring about their hostility which was something they wanted to avoid since the trierarchs were prominent figures of the Athenian scene. Consequently, they revised their first decision and in their report to Athens they did not make any reference to the trierarchs because they did not want to make enemies out of them. When they realized however that the Athenian people had been outraged at them and that they themselves were in danger of being held responsible and blamed, they dispatched a second report in which they clearly shifted the blame on to the two trierarchs. Reacting out of fear, they committed a grave error of assessment, because they spontaneously brought the two trierarchs in a position of defense (Kagan, 2004: p. 646). If the generals had not accused Theramenes, a man of great political influence, perhaps things would have been more favorable for them. In the first instance they thought things out reasonably, while in the second they succumbed to their fears with devastating consequences. However, the Athenian citizens (demos) also partook in a similar tergiversation during the trial of the accused generals in the Assembly. In the first meeting of the Assembly, without obvious emotional tension, the demos seem to have been convinced by the arguments of the generals. However, on the night of the trial, the relatives of the dead actually appeared at the Assembly with shaved heads in mourning, begging for the guilty to be punished (Xenophon, 1, 7, 8). The second meeting of the Assembly, under the pressure of the relatives of the dead, led directly to the 
generals' execution. Feelings were existent in both circumstances, leading however to completely contradictory decisions.

Is it possible for the entire demos, which embraces dialogue and adheres to democratic processes, carried away by extreme emotion, to behave immaturely and to commit acts that will permanently damage the demos itself in the near future? How can one justify such behavior?

The decision of the Athenians led to the death of the respected generals (Diodoros Siculus, 13, 102, 4). The Athenian citizens should at least have considered that the shortage of military leaders who are experienced and reliable in battle is disastrous during periods of war. With their unjust decision, they deprived their city of eight capable generals, including the two who were self-exiled, something which would have a devastating effect one year later in the naval battle in Aegospotami. Their attitude could be described as "blindness of the people" (De Romilly, 2006). When passions were quenched and religious fanaticism had subsided, the Athenians regretted the injustice they had committed against the generals, publicly denouncing and imprisoning the demagogues who had deceived the demos. Later, one of them, Callixenus, after having previously escaped, returned to Athens but was left to starve to death (Xenophon, 1, 7, 35). The question is whether repentance can remedy an act of frenzied injustice and unlawfulness. Of course, this is not the solution, because evil has already occurred.

Does the common sense of justice or does the law itself define the offense?

Does one have to abide by the unwritten laws under any circumstances, even if this means violating applicable laws and established rules? Of course, we are not referring to the personal meaning of justice, but to the common sense of justice.

The custom which is referred to as 'the ancient law of the Gods' obliged all living Greeks to attribute the due honor to the dead who fell heroically fighting in defense of the native land (Euripides, 563). The ideas of the Athenians are depicted in the tragedy "Antigone" of Sophocles, who is led to her death because, in keeping with the unwritten law, she disobeyed the order of King Creon and dared to bury her dead brother Polynices. Odysseus in the Homeric epic also goes down to Hades where he promises his comrade, Elpenor, that he will take care of the burial he is entitled to. After the battle of Marathon, the Athenians bury both their dead and the dead Persian warriors as it is appropriate. What differences do we find by contrasting the above events with the Athenian stance in the generals' trial?

Critical questions:

How is the unprecedented severity with which the Athenians managed this crisis explained? Can the confusion of war justify attitudes and behaviors based on impulse rather than the logical and sober handling of events?

The Athenian citizens disobeyed the law and allowed religious fanaticism 
along with the feelings of rage and indignation to obscure the sober and logical assessment of the circumstances (Aristotle, 34). On the other hand, it is perhaps certain that the team of trierarch Theramenes manipulated the demos, who in order to escape punishment, exercised everything in his power to influence it. The rigor of the decision had no precedent if we consider that the non-recovery of the dead after the naval defeat of the Athenians by Syracusians in $413 \mathrm{BC}$ had no consequences for them.

"most citizens (those participating in the Assembly) cried out that it is unheard of not to let the people do as they wish" (Xenophon, 1, 7, 8). Can the demos substitute the law and assert its omnipotence when critical historical decisions are involved?

This is not the only case of arbitrariness on the part of the demos, we only need to recall the condemnation of Socrates and Anaxagoras a few years later.

What is the role of historical figures when the issue concerns awakening the people during critical moments, something which is often carried out with the risk of depriving them of their personal freedom or even of their lives?

Socrates, was the only one of the Prytaneis, who was against the mass tribunal of the generals and who publicly expressed his opposition, despite the blaring crowd and the threat that he would be prosecuted and arrested (Plato, 32a-c). He himself, of course, did not avoid the death sentence shortly afterwards which was one more arbitrary decision of the Court of Heliaia (Castoriadis, 2011: pp. 282-283).

\section{The Teaching Approach}

In the school context, the following teaching approach could be integrated into the History lesson but could also be part of an interdisciplinary project of the wider area of Social Studies. With appropriate modifications, this syllabus can be addressed to students in the last two grades of Primary Education as well as to Secondary Education students. It includes narrations by the teacher, individual work of the students, discussion in the plenary as well as group work, as reflected in selected points of the teaching and learning process that is subsequently developed. Since the proposed teaching approach is based on empathic and experiential processes, it is necessary to conduct it in a supportive learning environment and to provide the time required for students to open up and draw on their personal experience without pressure and haste. The issue in question for the educational process is the ability to participate in a constructive dialogue, to conduct a critical enquiry of views and assumptions, and to accept alternative perspectives. What teachers and students need to avoid is the facility of stereotypical, established and binding perceptions. A more open, more thoughtful and functional approach tailored to the contemporary needs of both teachers and students should be employed as an alternative. It is not just about critical data processing, but about evaluating what we think and do, a process which can lead 
to a transformation of crystallized stereotypical positions. Since the development of these skills is considered to be an extremely important tool for the teacher, its inclusion in teacher training programs is highly recommended. If the educational act succeeds in becoming a transformative experience, it can lead to a real professional upgrade of the teacher whose benefits we hope will then be transferred to the teaching practice (Mezirow \& Taylor, 2009; Babalis, Tsoli, Artikis, Mylonakou-Keke, \& Xanthakou, 2013). Additionally, the teaching approach which follows could possibly be exploited in any adult education programs.

\subsection{Phase A}

\subsubsection{Posing a Critical Issue}

Students are introduced to the study of the historical event through one of the aforementioned critical issues, usually formulated in the form of a dilemma which is the focus of the lesson. Students are invited to contemplate on the critical issue and to write a short comment in which they will express their views and feelings. At this stage, no further clarifications are given, as what is requested is for thoughts and feelings to be expressed which are based on their own experiences and which are consistent with personal beliefs and cultural references. The comments are not communicated in the plenary, instead they are written down in order to be used in the final phase of the didactic approach.

\subsubsection{Narration of the Historical Event}

The students' first contact with the historical event takes place by the teacher narrating it to them or by the students studying relevant historical sources. It is possible for the narrative of the historical event not to be completed but to be interrupted at some critical point in order to stimulate the students' interest in the development of the incident. In this specific case, the narrative may be interrupted at the point where the accused generals are brought to trial before the Assembly, in order to emphasize the gravity of the dilemma faced by its members. They were called upon to decide on the fate of the accused generals, the triumphant warriors of the naval battle at Arginusae, who at the same time, however, were violators of a sacred duty. Students at this point are encouraged to recall a personal experience that is somewhat akin to the dilemma faced by the historical individuals (Endacott \& Brooks, 2013). The teacher activates thinking on the part of the students by asking questions such as: Have you ever faced a similar dilemma? What elements constituted this a difficult dilemma? What thoughts and feelings did it bring on? How was your personal dilemma similar and how did it differ from that which the historical persons faced? From the perspective of their personal experience, the students outline at a primary level the characteristics of the dilemma situation which they experienced and prepare cognitively and psychologically to work on the historical event. Their ideas are to be announced and discussed in the plenary session. 


\subsection{Phase B}

\section{A Deeper Processing of the Historical Events}

The teacher brings the students into contact with historical sources which refer to the historical event (text and translation) and directs the examination of the material based on a framework of critical sub-questions such as those mentioned above. The students, working in groups, point out the obscure points, formulate assumptions, look for causal associations and express their thoughts and feelings. The investigation is conducted in a critical spirit and reflective mood, and the claims are documented in the historical material. What is of the utmost importance at this stage of the investigation is the emergence of the historical and socio-cultural context which influenced or which in some cases even defined the historical development. Among the issues highlighted in the historical exemplary teaching approach being examined is how serious was the burial of the dead in the conscience of the Athenians and the severity of the situation in which the Athenians had fallen due to the war. At this stage, the teacher encourages students to approach the event in an empathic way. Through appropriate questions, they are encouraged to capture the historical event from the point of view of its historical protagonists in order to develop a deeper understanding of the intentions and actions of the historical individuals and to realize the different perspectives from which differentiated approaches and practices emerge (Yeager, Foster, Maley, Anderson, \& Morris III, 1998). At the end of the survey the teams report the results of their work, which, after being discussed, are listed in the table.

\subsection{Phase $C$}

\section{Presentation of the Group Work}

The students then work together in groups to present the results of the preceding survey in a plenary session. Dramatization, role play, the writing up of an empathic narrative or of an argumentative essay, creating art work representing the event are all activities that can take place at this stage (Babalis \& Tsoli, 2017). Taking advantage of the knowledge they have gained, they present the historical event in question from two or more perspectives, select arguments from each side and write alternative narratives. By activating empathic processes, they attempt to understand the way of thinking and action of the historical persons with whom they agree or disagree and support positions that are consistent or contrary to their own beliefs. The only commitment is the obligation to present the ideas, actions and feelings of historical persons which are relevant to the historical context to which they belong. Once the groups have presented, a class discussion ensues and the data which the students obtained is recorded. The teacher records the group data in the table next to the results of the previous phase in order to highlight their new enriched form.

\subsection{Phase D}

Transfer to the Present Time

At the end of the lesson, the students assess the decisions and actions of his- 
torical individuals and groups within their historical context. The judgment formulated should avoid the simplistic categorization of historical persons as victims and criminals. Instead, it should inspect with a critical and sober glance even those whose deeds have been condemned. In the light of the knowledge acquired by the students, they relate the past to the present, contrasting the ideas of historical persons with modern perceptions and assumptions, reflecting on and evaluating their own conscious or unrecognized thoughts and practices. Questions that can be asked at this stage are: What are the common points and what are the differences between modern perceptions and those of ancient Athens? Are the morals and beliefs of today as strong as they were in the past so as to raise fanaticism and violence? At what points would the historical event in question differ if it happened today? Are there people or groups of people who are experiencing similar situations in this day and age as those of the historical characters? Are there any assumptions, perceptions and behaviors which were wrong in the past and correct today or vice versa? A debate in a plenary session follows and a further enrichment of the data gathered is recorded in the table.

\subsection{Phase E}

\section{Deposit of Personal Experiences}

The teaching session concludes with a return to the personal experience. Students form groups of two and discuss the following questions: Have you ever been in a similar position, that is have you ever acted emotionally/impulsively against your values and have you regretted it afterwards? How did you handle this situation? How did you feel? Did your repentance correct the state of things? The personal experience is initially put up for discussion within the groups of two students which have been formed. The groups of two students are then merged to constitute four members, this time in an aim for the students to expose how they handled the incidents they discussed in their group of two, without specifically referring to them, and to share the feelings they experienced at that particular moment. They then try to group their experiences and to combine them by integrating them into more general contexts. They could organize their experiences on a three column table: What did I do? - Why did I do it? How did I feel? Next, they try to justify their reasoning of that particular moment. The groups present their results in a plenary session. At this point conflicting views are likely to arise and questions could remain unanswered. The teacher, in collaboration with the students, makes the most acceptable composition of the presentations, avoiding speaking about morality and extracting rules. Finally, students refer back to the comments they recorded in the first phase of the didactic approach. Individually, they examine whether questions and concerns were raised, whether they changed their original views and if the way in which situations were viewed has changed. Those who wish to, announce their conclusions during the plenary session. 


\section{Assessment of the Learning Process}

The assessment of the proposed didactic approach does not aim at appraising students in order to attain a grading of their performance. On the contrary, methods of evaluation which have been directly derived from the didactic/learning process are proposed and are closely linked with the nature of the content of the specific lesson being taught and with the didactic context in which learning takes place (Herman, Osmundson, Ayala, Schneider, \& Timms, 2006). They are also associated with individual student factors such as personal cognitive development, past learning experiences, attitudes, student inclinations and interests (Olwell \& Raphael, 2006: p. 222). In this sense, the assessment proposed in this paper can take place at any moment throughout the teaching/learning process as an integral and undifferentiated part of it and serves primarily the purpose of formative assessment and feedback (Black, Harrison, Lee, Marshall, \& Wiliam, 2003). As a result, the educational activities developed in the above didactic approach function simultaneously as assessment procedures since by implementing them a continuous flow of information is available and immediately exploitable in an aim to improve both students' performance at the cognitive, social and emotional level as well as the didactic/learning process itself (Black \& Wiliam, 2009, Darling-Hammond, \& Snyder, 2000).

Additionally, with its formative and feedback function, evaluation of the learning process in mention can be realized with supplementary activities that will take place at the end of the lesson. By applying these activities, the teachers are equipped with additional information regarding the performance of their students and the degree to which the curriculum objectives are met, while at the same time students are offered with additional opportunities to further enrich and extend the essential content of the lesson which has been taught (Wiliam, 2010: p. 24; Brookhart, 2010). As such assessment techniques, we would propose the critical investigation of written and visual sources, the production of empathic texts and speech, the creation of artistic work and the performance of educational drama. It is obvious that these alternative assessment techniques do not differ substantially from the educational activities which have already been proposed during the processing of the lesson. Although they are selected to serve the needs of the assessment, they also offer students the opportunity to critically reflect and analyze the historical content, to familiarize themselves with the historical method and to link historical events with the problems of modern life. By exploiting these techniques, with more or less guidance, students work collectively, share ideas, pose and answer questions, participate in multi-sensory experiences in an effort to develop a further personal understanding of the historical content they are dealing with (Postholm, 2006). Conventional techniques that could be combined with alternative techniques in the assessment of the learning process are presenting selected points orally, conducting a webquest, replying to short answer questions, posing an open question which requires an extended answer or the carrying out of a small team project. We would not even rule out 
the use of a cognitive multiple-choice questionnaire or the construction of a concept map, as long as our evaluation serves a formative and feedback function. In the context of the combination of conventional and alternative forms of evaluation, students are encouraged to perform the selected assessment activities in a way that is consistent with their personal learning styles and their individual interests, rendering as accurately as possible the complexity of historical situations and the intricate nature of human issues.

\section{Conclusions and Proposals}

The empathic approach seeks to understand the other individual and through empathy to grasp an understanding of our own self. The ultimate goal is to provoke questioning and contemplation that will lead to catharsis of stereotypical views. The attempt to disengage from such assumptions is an arduous and often challenging process, which should be done progressively so that the teacher, and of course the students, can come to comprehend its purpose and their own role in achieving that goal.

In order for an empathic educational approach to yield the anticipated benefits in an educational context:

- The selection of historical sources should stimulate students' interest and facilitate the empathic approach. The historical event should come to life through the content of the historical sources so as to reveal its various aspects and nuances. Moreover, it should facilitate the mental reconstruction of the historical events.

- The empathic process should not unintentionally harm, the students' emotional world. The question is whether students should be called upon to take on the roles of individuals and groups who have committed abusive acts. The easy answer would be: adults could be allowed to do so; however in school it is prohibited. However, when students are involved in experiential teaching techniques such as educational drama with specific pedagogical aims and when they are encouraged to think seriously about the events with the guidance of the teacher, it is possible to make more demanding or challenging dramatic representations.

- Critical thinking and reflection should be put into effect, even at an early stage. To accomplish this, special attention should be paid to transferring historical knowledge from the historical person to others living at the present time and to our own self. The educational process should provide the teacher, and to some extent the students, with the chance to critically explore the origins of their assumptions and offer the opportunity to review the validity of their thoughts and habits. In this way, they will be enabled to become aware of their contradictions and be in a position to be in touch with their own feelings in a more appropriate manner.

- Teachers should be encouraged to participate in training programs so that they can have the opportunity to experience the empathic experience first 
before applying it to their students. Otherwise, there is a risk that the empathic methodological approach will become a superficial academic activity, which will fail to have an impact on the students, since it initially failed in moving the teacher.

\section{Conflicts of Interest}

The authors declare no conflicts of interest regarding the publication of this paper.

\section{References}

Babalis, T., \& Tsoli, K. (2017). Classroom Life: Shaping the Learning Environment, Classroom Management Strategies and Teaching Techniques. New York: Nova Publishers.

Babalis, Th., Tsoli, K., Artikis, C. T., Mylonakou-Keke, I., \& Xanthakou, Y. (2013). The Impact of Social and Emotional Learning Programs on the Emotional Competence and Academic Achievement of Children in Greek Primary School. World Journal of Education, 3, 54-63. https://doi.org/10.5430/wje.v3n6p54

Black, P. J., \& Wiliam, D. (2009). Developing the Theory of Formative Assessment. Educational Assessment Evaluation and Accountability, 1, 5-31.

https://doi.org/10.1007/s11092-008-9068-5

Black, P., Harrison, C., Lee, C., Marshall, B., \& Wiliam, D. (2003). Assessment for Learning. Putting It into Practice. Maidenhead: Open University Press.

Brookhart, S. M. (2010). Formative Assessment Strategies for Every Classroom: An ASCD Action Tool (2nd ed.). Alexandria, VA: Association for Supervision \& Curriculum Development.

Castoriadis, C. (2011). Thucydide, la force et le droit. Ce qui fait la Grèce. Seuil: La Création Humaine IV. https://doi.org/10.14375/NP.9782021036626

Darling-Hammond, L., \& Snyder, J. (2000). Authentic Assessment of Teaching in Context. Teaching and Teacher Education, 16, 523-545.

https://doi.org/10.1016/S0742-051X(00)00015-9

De Romilly, J. (2006). Problèmes de la démocratie grecque. Collection Savoir Culture, Paris: Hermann.

Endacott, J., \& Brooks, S. (2013). An Updated Theoretical and Practical Model for Promoting Historical Empathy. Social Studies Research and Practice, 8, 41-58.

Foster, S. J. (2001). Historical Empathy in Theory and Practice: Some Final Thoughts. In O. L. Davis Jr., E. A. Yeager, \& S. J. Foster (Eds.), Historical Empathy and Perspective Taking in the Social Studies (pp. 167-179). Lanham, MD: Rowman \& Littlefield Publischers Inc.

Goldberg, T., \& Savenije, G. M. (2018). Teaching Controversial Historical Issues. In S. A. Metzger, \& L. McArthur Harris (Eds.), The Wiley International Handbook of History Teaching and Learning (pp. 503-526). New York: Wiley-Blackwell. https://doi.org/10.1002/9781119100812.ch19

Herman, J. L., Osmundson, E., Ayala, C., Schneider, S., \& Timms, M. (2006). The Nature and Impact of Teachers' Formative Assessment Practices. CRESST Report 703, Los Angeles, CA: UCLA National Center for Research on Evaluation, Standards, and Student Testing.

Jenkins, K. (1991). Re-Thinking History. London: Routledge. 
Kagan, D. (2004). The Peloponnesian War. New York: Penguin Books.

Lazarakou, E. D. (2008). Empathy as a Tool for Historical Understanding: An Evaluative Approach of the Ancient Greek Primary History Curriculum. International Journal of Social Education, 23, 27-46.

Lazarakou, E. D. (2009). Historical Imagination as an Evaluative Criterion for Student Performance in the Subject of History: The Revolt of Mytilene from the Athenian League. Ekklesiastikos Pharos, 91, 82-93.

Lee, P., \& Ashby, R. (2001). Empathy, Perspective Taking, and Rational Understanding. In O. L. Davis Jr., E. A. Yeager, \& S. J. Foster (Eds.), Historical Empathy and Perspective Taking in the Social Studies (pp. 167-179). Lanham, MD: Rowman \& Littlefield Publishers Inc.

Lee, P., \& Shemilt, D. (2011). The Concept That Dares Not Speak Its Name: Should Empathy Come Out of the Closet? Teaching History, 143, 39-49.

Lemisko, L. S. (2004). The Historical Imagination: Collingwood in the Classroom. Canadian Social Studies, 38, 1-9. https://files.eric.ed.gov/fulltext/EJ1073911.pdf

Mezirow, J., \& Taylor, E. W. (2009). Transformative Learning in Practice. Insights from Community, Workplace and Higher Education. San Francisco, CA: Jossey-Bass.

Olwell, R., \& Raphael, N. (2006). The Problems of Elementary Social Studies: Are Curricular and Assessment Sprawl to Blame? Social Studies, 97, 222-224.

https://doi.org/10.3200/TSSS.97.5.222-224

Phillips, I. (2009). Teaching Sensitive and Controversial History. In S. Aktekin, P. Harnett, M. Ozturk, \& D. Smart (Eds.), Teaching History and Social Studies for Multicultural Europe (pp. 117-126). Ankara: Harf Egitim Yayıncılı̆ı̆.

Postholm, M. B. (2006). Assessment during Project Work. Teaching and Teacher Education, 22, 150-163. https://doi.org/10.1016/j.tate.2005.09.006

Shemilt, D. (2011). The Gods of the Copybook Headings: Why Don't We Learn from the Past? In L. Perikleous, \& D. Shemilt (Eds.), The Future of the Past: Why History Education Matters (pp. 69-127). Nicosia: Association for Historical Dialogue and Research.

Tsoli, K. (2019). Active Citizenship: The Contribution of Experiential Learning and Critical Education. Journal of Contemporary Education and Culture, 11, 6-13.

Wiliam, D. (2010). An Integrative Summary of the Research Literature and Implications for a New Theory of Formative Assessment. In H. L. Andrade, \& G. J. Cizek (Eds.), Handbook of Formative Assessment (pp. 18-40). New York: Taylor \& Francis.

Yeager, E. A., Foster, S. J., Maley, S. D., Anderson, T., \& Morris III, J. W. (1998). Why People in the Past Acted as They Did: An Exploratory Study in Historical Empathy. International Journal of Social Education, 13, 8-24.

\section{Ancient Greek Sources}

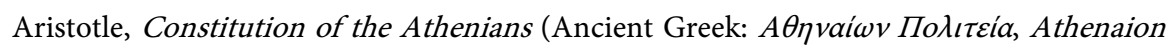
Politeia)

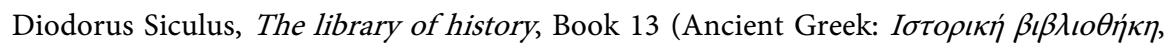
Historiki bibliothiki, Roman: Bibliotheca historica)

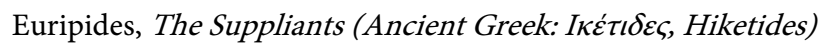

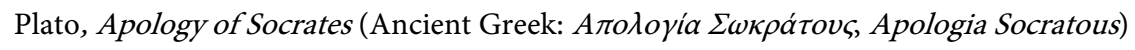

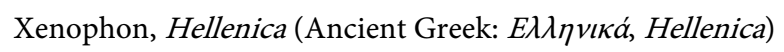

